DOI: https://doi.org/10.34069/AI/2022.49.01.28 How to Cite:

Kramarenko, A., Stepaniuk, K., Bogdanov, I., Alieksieieva, H., Kempińska, U. (2022). The educational component "Teaching methodology of social and health-care educational sector" under quarantine restrictions. Amazonia Investiga, 11(49), 259-266. https://doi.org/10.34069/AI/2022.49.01.28

\title{
The educational component "Teaching methodology of social and health-care educational sector" under quarantine restrictions
}

\section{Освітня компонента «Методика навчання соціальної та здоров'язбережувальної освітньої галузі» в умовах карантинних обмежень}

Received: November 25, 2021
Accepted: January 9, 2022

Written by:

Alla Kramarenko ${ }^{109}$ https://orcid.org/0000-0003-3922-4979

Katerina Stepaniuk ${ }^{\mathbf{1 1 0}}$

https://orcid.org/0000-0002-5379-8402

Igor Bogdanov ${ }^{111}$

https://orcid.org/0000-0002-3035-7989

Hanna Alieksieieva ${ }^{112}$

https://orcid.org/0000-0003-3204-3139

Urszula Kempińska ${ }^{113}$

https://orcid.org/0000-0003-1922-8219

\section{Анотація}

У статті розглядаються теоретичні та практичні аспекти організації змішаного навчання майбутніх учителів початкової школи в умовах карантину, спричиненого COVID-19. На прикладі освітньої компоненти «Методика навчання соціальної та здоров'язбережувальної освітньої галузі» схарактеризовано особливості організації освітнього процесу у змішаному форматі, а саме: наведено зразки завдань, що дозволяють сформувати громадянські та соціальні компетентності здобувачів першого рівня вищої освіти в умовах нових викликів часу. У статті акцентовано увагу на особливостях роботи у віртуальному освітньому середовищі Moodle, узагальнено власний педагогічний досвід викладання освітньої компоненти «Методика навчання соціальної та здоров'язбережувальної освітньої галузі», запропоновано авторську методику структурування та змістового наповнення освітньої компоненти, що відображено у навчальному посібнику, розглянуто необхідність застосування цифрових інструментів Canva, Padlet. Coggle

\footnotetext{
${ }^{109}$ Doctor of Pedagogical Sciences, Professor, The Head of the Department of elementary Education, Berdiansk State Pedagogical University, Berdiansk, Ukraine.

${ }^{110} \mathrm{PhD}$ of Pedagogical Sciences, Associate Professor, Berdiansk State Pedagogical University, Berdiansk, Ukraine.

${ }^{111}$ Doctor of Pedagogical Sciences, Professor, Rector of Berdiansk State Pedagogical University, Berdiansk, Ukraine.

${ }^{112} \mathrm{PhD}$ of Pedagogical Sciences, Associate Professor, Berdiansk State Pedagogical University, Berdiansk, Ukraine.

${ }^{113}$ Dr, Director of the Institute of Pedagogy, Cuiavian University in Włocławek, Poland.
} 
given. The article presents the results of a survey of applicants for the first level of higher education program 013 Primary Education, which show that students have a generally positive attitude to using digital tools Canva, Padlet, Coggle, as it positively influences the formation of their professional competence and the formation of their own methodological system. The author's method suggested in this article is incomplete and is continually being improved in accordance with time challenges.

Keywords: professional training, future teachers, educational component, educationalresearch tasks, blended learning, digital tools, Moodle platform.

\section{Introduction}

At the beginning of 2020, in conjunction with the global pandemic and quarantine restrictions distance technologies were launched as one of the main thrusts of reform and strategic development of the education system around the world (Adams, 2020; Germann et al, 2019; UNESCO, 2020). Therefore, the demand for online learning and the digitalization of the education system is growing as ever. As a result, the Ministry of Education and Science of Ukraine has recommended higher education institutions to organize the educational process remotely. This is stated in the Recommendations to make changes to the educational process timetable and the classes schedule.

UNESCO statistics on the mass transition to distance learning in a pandemic show that as of April 2020 only 53\% of teachers in developed countries had experience of online teaching (UNESCO, 2020). In Ukraine, according to the government, less than $30 \%$ of Ukrainian children could qualitatively study in quarantine, and only about $20 \%$ of teachers were ready for distance learning (Lytvyn, 2020).

The report of the World Economic Forum identifies new models of education for the School of the Future in preparation for the Fourth Industrial Revolution. In particular, it is emphasized that Education 4.0 should be aimed at developing 8 skill sets, including digital and technological (World Economic Forum, 2020). The New Ukrainian School requires a teacher able to develop 10 key competences, including для організації групової роботи студентів під час змішаного навчання в умовах карантину, спричиненого COVID-19, а також наведено зразки виконання завдань майбутніми учителями початкової школи. Висвітлено результати опитування здобувачів першого рівня вищої освітньої програми 013 Початкова освіта, які свідчать, що студенти загалом позитивно сприймають застосування цифрових інструментів Canva, Padlet. Coggle, оскільки це позитивно впливає на формування їх професійної компетентності та формуванню власної методичної системи. Пропонована у статті авторська методика не $\epsilon$ завершеною і постійно вдосконалюється 3 урахуванням викликів часу.

Ключові слова: майбутні учителі, освітня компонента, навчально-дослідницькі завдання, змішане навчання, цифрові інструменти, платформа Moodle.

civic and social competences (New Ukrainian school, 2017).

The author and developer of the education component Alla Kramarenko is a participant in the "Learning Together" project (barna-consult), which implies support of Finnish experts to reform school education in Ukraine. In general, the project aims to improve the quality of education and public acceptance of Ukrainian education. The project's ideas were used in the development of the textbook and the content of the educational component "Teaching methodology of social and health-care educational sector".

Thus, the challenges of the time require new approaches to the training of future primary school teachers and the formation of new forms of cooperation between teachers and students using online tools under a Global pandemic and quarantine restrictions (Apshay et. al., 2021).

\section{Literature Review}

The problem of training teachers for primary schools has always been a topical issue, and many educators have devoted a large volume of their research to solving this problem: Koval (2020), Kramarenko and Stepaniuk (2021), Bezlyudna and Dudnyk (2021) and others.

The problem of training a primary school teacher for distance learning practice is described by N. Bezlyudna \& N. Dudnyk (2021); the problem 


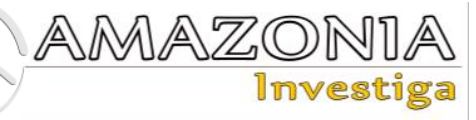

of training a primary school teacher for distance learning practice is described by N. Bezlyudna \& Dudnyk (2021); professional training of future English language teachers by means of distance learning in universities of the Republic of Poland is outlined by A. Shtepura (2018); psychological and pedagogical foundations of teachers' and students' readiness to use distance learning tools in foreign experience are presented in studies by G. Chorab (2016), A. Postola (2017).

The problem of training future teachers for the primary level of general secondary education becomes especially relevant in connection with the implementation of (Hrynevych, 2016) and the updated State Standard of Primary Education (Decree No. 87, 2018).

One of the main tasks of training future teachers of the New Ukrainian School is to form the ability to organize the purposeful formation of competencies, to ensure content integration (intra- and interdisciplinary) on the basis of key competencies, not by mechanistic integration of subjects, but by aligning the content of education with the sensitive periods of learning, the specifics of perception of new information, etc. (Hrynevych, 2016).

This requires higher education institutions to find ways of improving the professional training of students studying in the 013 Primary Education programs (Chuchalina et. al., 2021).

Thus, according to the educational program 013 Primary Education of the first level of higher education, future primary school teachers have to possess knowledge, practical skills and teaching methods and capably use them in solving pedagogical, educational and scientificmethodological tasks in primary school.

The aim of the article is to discuss the peculiarities of professional methodological training of primary school teachers in the conditions of distance learning at Berdiansk State Pedagogical University on the example of the course "Teaching methodology of social and health-care educational sector" (Kramarenko \& Stepaniuk, 2021).

\section{Methodology}

In working on the study, we used the following methods. Theoretical: analysis of the initial base of the remote organization of the educational process; synthesis, generalization, comparison to reveal the features of professional training of future teachers in the conditions of mixed and distance learning; modeling - to adapt the design of the course "Methods of teaching social and health education" to the conditions of distance learning. Empirical: diagnostic (assessment of independent work of students of higher educational institutions) - to determine the ability to use online tools Canva, Padlet, Coggle.

\section{Results and Discussion}

The methodological support of the training process of future primary school teachers includes designing and conducting various types of educational activities in the disciplines of the professional training cycle of education program 013 Primary Education in the conditions of blended and distance learning (Koval \& Kramarenko, 2020).

In the circumstances of the pandemic we have to react and adapt to time challenges very quickly, that is why we believe that one of the most efficient ways to organize distance learning is to work with complete educational and methodological complex of the course in the system of e-learning (based on Moodle platform) of Berdiansk State Pedagogical University (https://edu.bdpu.org/course/view.php?id=279).

Within the article we will consider the tasks we have developed for practical and self-study work for first-level higher education students in the course "Teaching methodology for social and health-care education sector"' (Stepaniuk, 2021).

The work organization on the platform allows systematic and holistic learning of the course and facilitates the organization of interaction between the teacher and students through easy file sharing; setting of time limits for the completion of tasks; rapid organization of educational discussion of tasks; a user-friendly automated system for assessment of students' assignments; the option of individual communication between the tutor and the student; control of student activity and their study hours in the network; course structuring, thematic units, etc.

The potential of the distance learning platform makes it possible to define new competencies and functions of the teacher in the educational process - he/she becomes a tutor, a facilitator, as interacts with students online, organizes their online workspace using the platform's infrastructure, develops educational material, defines goals and creates course content, provides guidelines on how to work with the information in the network, etc (Hurenko et. al., 2017; Koufou \& Tsilichristou, 2014). 
To optimize, intensify and diversify the educational process it is recommended to use various electronic resources, offering students a variety of tasks for processing, reproducing and presenting learning material.

Below we will look at the peculiarities of professional methodological training of higher education students under distance learning conditions (based on the Moodle platform) through the example of the course "Teaching methodology of social and health-care educational sector".

Under quarantine restrictions, we adapted the design of the course "Teaching methodology of social and health-care educational sector" to the environment of distance learning and implemented it for the 3rd year students of The Faculty of Psychological and Pedagogical Education and Arts. The design of the discipline was focused on achieving its goal: mastering the program learning outcomes and the formation of professional competencies and personal qualities of future primary school teachers.
The course consists of lectures on the Zoom platform, tasks for practical, self-study and individual work on the Moodle platform. All of the tasks were adapted to the distance learning conditions. Each of them had its own grading criteria, which were announced to the students at the beginning of the course and specified in the syllabus.

We present some samples of tasks for self-study, which are appropriate for first-level higher education students in the 013 Primary Education program. The tasks are available on the Moodle education platform (https://edu.bdpu.org/course/view.php?id=279):

1. Summarize the experience of educatorspractitioners in organizing a health-care educational environment in the New Ukrainian School, identifying the similarities and differences in their work. Identify innovative approaches and assess their level of novelty (Figure 1).

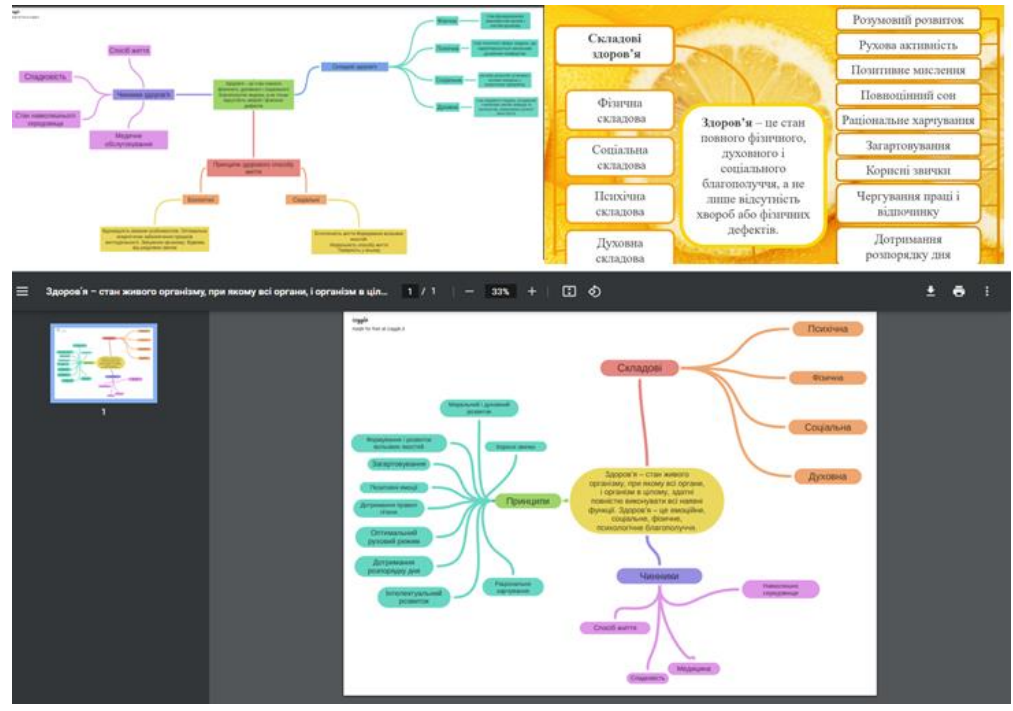

Figure 1. An example of using the coogle service.

2. Using the Coogle service (https://coggle.it), create a mind map of the definition of "health" (Gorbatiuk et. al., 2019; Krauthausen, 2013; Kravchenko, 2018).

3. Develop a script for a morning meeting for 1st graders (choose your own topic of the week) and prepare to simulate it with your group of students.

4. Select games (at least 5) that contribute to the development of auditory and locomotormovement attention, switching children from one type of activity to another in the studying the course "I explore the world" (Figure 2).

5. Create an infographic on "Implementing health-care education ideas in the New Ukrainian School" using the Canva service (https://www.canva.com).

6. Develop information for a project for primary school pupils on "How does advertising influence choice of products?" in the course "I explore the world". Post the information on the Padlet virtual board (https://uk.padlet.com) (Jaros, 2012). 


\section{AMAZONIA
Trvestiga}

Thus, under the conditions of quarantine restrictions, the self-study of higher education students acquires specific features and requires the use of online tools (Josefsson et. al., 2019). The tasks we have developed are effective for the formation of professional competencies and

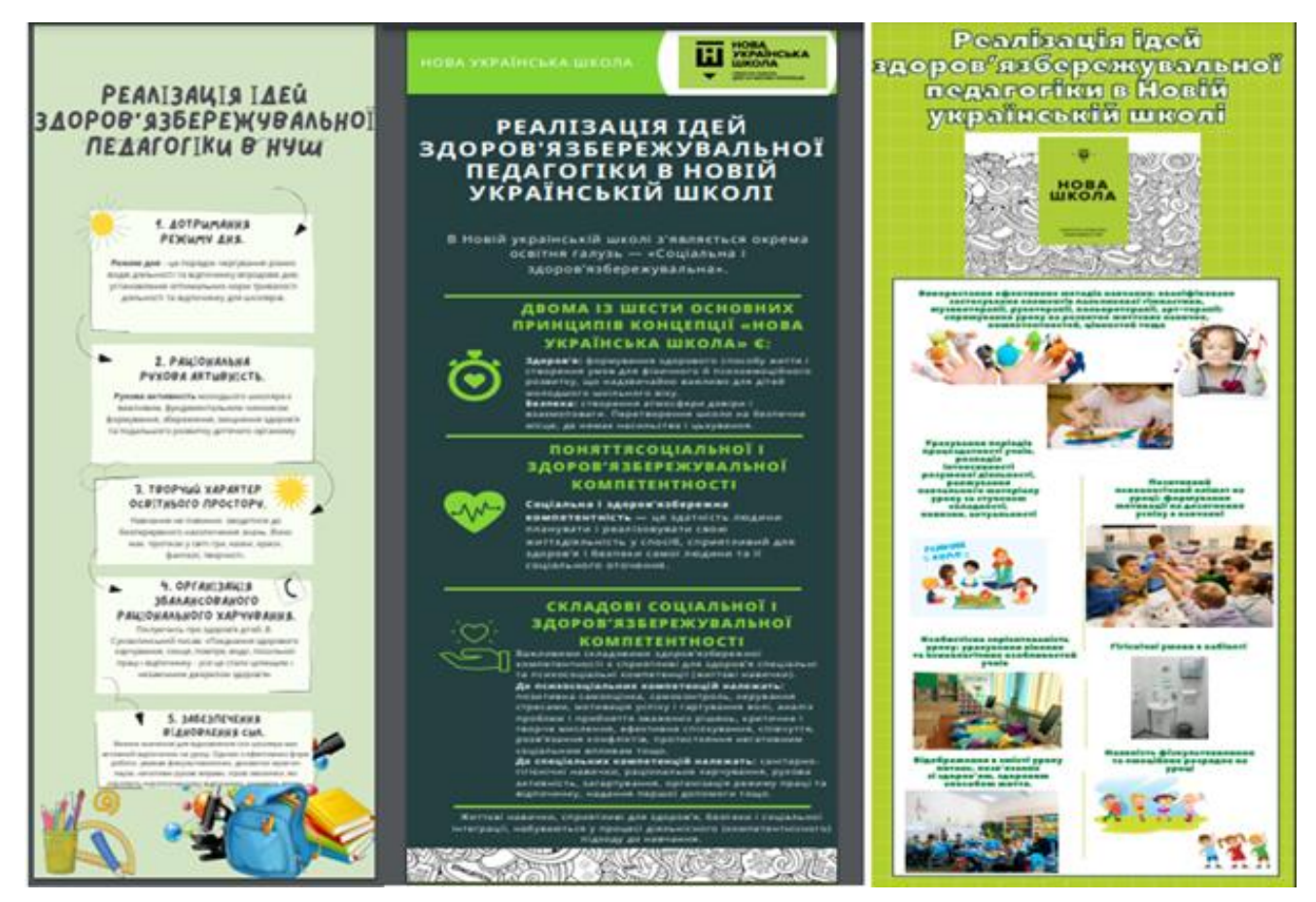

readiness of future primary school teachers to work in the New Ukrainian School in the classroom, distance and blended learning as they contribute to more conscious, independent and creative mastery of indirect interaction services in the educational process.

Figure 2. An example of using the Canva service.

Within the course "Teaching methodology of social and health-care educational sector" we also use educational and research tasks, that involve higher education students to understand the problem situation, identify the main contradiction, implement the process of solving the problem, proving the correctness of conclusions and more. The system of didactic tasks is based on the levels of cognitive independence of future teachers which integrate quantitative and qualitative features of self-study work (Shchetynina et. al., 2019; Kordaki \& Kakavas, 2017). Qualitative changes in the nature of the conclusions that lead to the solution of the problem play a dominant role here. Levels of cognitive independence can be considered as a means of managing the development of students' cognitive activity and diagnosing their cognitive abilities (Prokopenko et. al., 2020).

It should be noted that the formulation of these tasks for higher education students consists of the following stages:

1. Problem definition in the question or task form.
2. Discussing options for solving the problem, instructing on completing the task.

3. Implementation of the chosen solution to the problem.

4. Development of tasks and questions for students' self-control.

5. Discussion of work results, error correction.

6. Using search results when studying new material or solving another problem.

As a rule, such tasks serve as a means of individuating the training of primary school teachers, develop motivation for educational activity, and provide mastering of research creativity.

We have proposed the following sequence of educational and research tasks:

- identify the problem for formulating the task conditions, based on the concepts of national and international pedagogy;

- devise ways of solving the problem;

- $\quad$ argue the feasibility of each variant.

Following is a brief overview of the proposed educational-research tasks, which we use in the 
process of professional training of future primary school teachers within the study of the course "Teaching methodology of social and health-care educational sector".

Here are some samples for introduction.

Educational-research task 1. Analyze the video recordings of the lessons "I explore the world" course and find out how the competence-based approach to the formation of life skills of primary school pupils was realized in the educational process.

Educational-research task 2. Elaborate the requirements for registration of research results and project presentation script "The $\mathrm{ABC}$ of Nutrition".

Educational-research task 3. Give examples of topics for different types of projects in the course "I explore the world". Supplement them with other attributes (the nature of the contacts, the duration of the activity, the number of participants). For each characterized type of project identify the problem, formulate the goal and task, indicate the interdisciplinary links, propose the option of designing the project results and its practical relevance (Kramarenko \& Stepaniuk, 2021).

Completing of these tasks allowed to stimulate the cognitive processes and activity of future primary school teachers and ensured the formation of theoretical style of students' thinking, the training of research methods, and the development of professionally significant qualities of the personality under distance learning conditions.

When completing such tasks, students make assumptions about ways to solve a problematic situation, summarize previously acquired knowledge, discover the causes of situations, explain their origin, and choose the most rational solution for a problematic situation. The teacher must lead this process at all stages, including through questions-prompts.

Therefore, educational and research tasks are effective for the formation of professional competencies and readiness of future primary school teachers to work in distance learning conditions, as they contribute to a more conscious and self-directed mastery of the future pedagogical activity (Popa et. al., 2015).

In the context of the implementation of the new State Standard for Primary Education, it is important to draw the attention of future primary school teachers to the necessity of changing the spatial environment, programs and teaching tools in the New Ukrainian School.

At the demands of the time, the Berdiansk State Pedagogical University has established a primary education laboratory to reproduce the New Ukrainian School's educational environment for training students of the first and second levels of higher education according to educational programs 013 Primary Education. The lecturers of the Department of Primary Education at BSPU have developed their own design for the laboratory, taking into account the color scheme between walls, furniture, appropriate classroom equipment, sun shutters and individual desks, which can be easily combined into various combinations for pair and group activities. In the conditions of blended learning lectures are conducted by teachers in the laboratory, which enables to demonstrate the techniques of working with didactic material in the laboratory educational environment through video conferencing on the Zoom platform.

\section{Conclusions}

Based on the analysis of scientific sources, studying and summary of pedagogical experience we have reached the following conclusions. This study has shown that in the context of quarantine restrictions during a worldwide pandemic, it is important to effectively organize the distance work of higher education students. For this purpose, we have proposed the author's approach to work in the virtual learning environment Moodle on the educational component "Teaching methodology of social and health-care educational sector". The use of digital tools Canva, Padlet, Coggle for the organization of group work of students during the blended learning period indicates an increased interest of higher education students in their future professional activities and the formation of their own portfolio of creative works, in particular, this is achieved through the completion of educational and research tasks.

The author's method for training the educational component "Teaching methodology of social and health-care educational sector" proposed in the article is not complete and is constantly being improved over time, especially under the quarantine conditions caused by COVID-19. It can be recommended as an effective workable method in the training of future teachers in general, and primary school in particular. 


\section{AMAZOND風}

Bibliographic references

Adams, R. (2020). UK Universities Facing $£ 760$ $\mathrm{m}$ Hit as one in Five Students Plan to Defer. Support the guardian. https://www.theguardian.com/education/202 0/may/20/uk-universities-facing-760m-hitone-in-five-students-plan-defer

Apshay, N., Sherstneva, I., Apshai, M., \& Stepaniuk, K. (2021). Organizational and commercial tools of supervision and development of competitiveness of education. AD ALTA. Journal of Interdiscsplinapy Research, 11(10), 6-10. http://www.magnanimitas.cz/ADALTA/110 115/PDF/110115.pdf

Bezlyudna, N., \& Dudnyk, N. (2021). Preparation of the future primary school teacher for pedagogical practice in the conditions of distance learning. Psychological-pedanic problems of modern school [Psykholoho-pedahohichni problemy suchasnoi shkoly], 1, 26-32. https://doi.org/10.31499/27066258.1(5).2021.234763

Chuchalina, $\quad$ Y.M., Kramarenko, A.N., Komar, O.A., Torchynska, T.A., \& Shevchuk, I.V. (2021). Agile approach in training future primary school teachers for resolving complex pedagogical situation. International Electronic Journal of Elementary Education, 13(4), 469-477. http://dx.doi.org/10.26822/iejee.2021.205

Chorab, G. (2016). The Brain Against New Technologies: Threats and Losses [Mózg wobec Nowych Technologii: Zagrożenia i Straty]. General and Professional Education, 1, 9-15. https://docplayer.pl/23538929Mozg-wobec-nowych-technologiizagrozenia-i-straty-the-brain-to-newtechnologies-the-risks-and-losses.html

Decree No. 87. State standard of primary education. Cabinet of Ministers of Ukraine on February 21, 2018 [Electronic resource]. https://www.kmu.gov.ua/npas/prozatverdzhennya-derzhavnogo-standartupochatkovoyi-osviti

Germann, T.C., Gao, H., Gambhir, M., Plummer, A., Biggerstaff, M., Reed, C., \& Uzicanin, A. (2019). School Dismissal as a Pandemic Influenza Response: When, Where and for ow Long? https://www.sciencedirect.com/science/articl e/pii/S1755436518301749?via \%3Dihub

Gorbatiuk, L.V., Kravchenko, N.V., Alekseeva, H.M. \& Rozumna, T.S. (2019). Mobile applications as a means of foreign language lexical competence formation of non-philological specialties' students.
Information Technologies and Learning Tools, 74 (6), 150-164. https://doi.org/10.33407/itlt.v74i6.2529

Hrynevych, L. (2016). The concept of the New Ukrainian School. Ministry of Education and Science of Ukraine https://rada.info/upload/users_files/4395247 2/e74a979f4f08da6b69a20b361f400756.pdf

Hurenko, O. I., Alekseeva, H. M., Lopatina, H. O., \& Kravchenko, N. V. (2017). Use of computer typhlotecnologies and typhlodevices in inclusive educational space of university. Information Technologies and Learning Tools, 61(5), 61-75.

https://doi.org/10.33407/ITLT.V61I5.1782

Jaros, I. (2012). Teachers' digital competence vs. the use of information and communication technologies in early education. Young researchers Forum. Forum of young researchers [Forum mladych vyskumnikov], $7-11$.

https://www.webofscience.com/wos/woscc/f ull-record/WOS:000396943000002

Josefsson, P., Jaa-Aro, K.M., \& Berrez, A.M. (2019). The implementation of digital tools in teaching: a qualitative case study at a swedish primary school. 11th International Conference on Education and New Learning Technologies (EDULEARN), 2382-2387. https://www.webofscience.com/wos/woscc/f ull-record/WOS:000551093102070

Kordaki, M., \& Kakavas, P. (2017). Digital tools used for the development of computational thinking in primary education: a ten year systematic literature review. 9th International Conference on Education and New Learning Technologies (EDULEARN), 6346-6356 https://www.webofscience.com/wos/woscc/f ull-record/WOS:000493048101064

Koufou, A. \& Tsilichristou, E. (2014). Digital concept mapping in cultural education. 5th International Conference on Information, Intelligence, Systems and Applications (IISA), IISA 2014, 238-248. https://www.webofscience.com/wos/woscc/f ull-record/WOS:000345861900067

Koval, L., \& Kramarenko, A. (2020). Improving the quality of professional training of future specialists in primary education: a collective monograph. Melitopol, 368. https://dspace.bdpu.org/bitstream/12345678 9/3505/1/Pidvyshchennya\%20yakosti\%20pr ofesiynoyi\%20pidhotovky\%20maybutnikh\% 20fakhivtsiv\%20pochatkovoyi\%20osvity.pd $\mathrm{f}$

Kramarenko, A., \& Stepaniuk, K. (2021). Methods of teaching social and health education in primary school. Melitopol. 
Vydavnychyi building of Melitopolskai printing house, 193. https://dspace.bdpu.org/bitstream/12345678 9/4418/1/Metodyka\%20navchannya\%20sots ial\%CA\%B9noyi\%20ta\%20zdorov\%27yazb erezhuval\%CA\%B9noyi\%20osvitn\%CA\%B 9oyi\%20haluzi\%20v\%20pochatkoviy\%20sh koli.pdf

Krauthausen, G. (2013). Digital tools in elementary mathematics education. International Symposium on Elementary Maths Teaching (SEMT). Tasks and tools in elementary mathematics, 33-44. https://www.webofscience.com/wos/woscc/f ull-record/WOS:000329448800003

Kravchenko, N., Alyeksyeyeva, H., \& Gorbatyuk, L. (2018). Curriculum Optimization by the Criteria of Maximizing Professional Value and the Connection Coefficient of Educational Elements, Using Software Tools. ICTERI 2018. 14th International conference on ict in education, research, and industrial applications. [Electronic resource]. Kyiv, Ukraine. CEUR Workshop Proceedings, 1, 365-378. http://ceur-ws.org/Vol-2105/

Lytvyn, Z. (2020). Has COVID-19 become a black swan for Ukrainian education? NV Premium, https://nv.ua/ukr/biz/experts/distanciynenavchannya-pomilki-ta-heyt-shcho-ne-takiz-ukrajinskoyu-sistemoyu-osviti50082890.html

New Ukrainian school (2017). A guide for teachers. Kyiv, Pleiades Publishing House, $206 . \quad$ https://nus.org.ua/wpcontent/uploads/2017/11/NUSH-poradnykdlya-vchytelya.pdf

Popa, D., Bazgan, M., \& Palasan, T. (2015). Teachers' perception about using digital tools in educational process. EDULEARN15: 7TH International conference on education and new learning technologies, 7994-7998. https://www.webofscience.com/wos/woscc/f ull-record/WOS:000376685708010

Postola, A. (2017). Digital Natives do not exist! Most Young People are just Passive Media Recipients [Cyfrowi Tubylcy nie Istnieją! Większość Młodych Ludzi jest tylko
Biernymi Odbiorcami Mediów]. Wyborcza, https://wyborcza.pl/7,75400,22486632,cyfro wi-tubylcy-nie-istnieja-wiekszosc-mlodychludzi-jest-tylko.html

Prokopenko, A., Vozniuk, A., Leshchenko, H., Manchulenko, L., Kramarenko, A., \& Mondich, O. (2020). Activization of Cognitive Activity of Students in Higher Education Institutions. Systematic Reviews in Pharmacy, 11 (10), 144-146.

Shchetynina, O., Kravchenko, N., Alyeksyeyeva, H., \& Gorbatyuk, L. (2019). Project Management Systems as Means of Development Students Time Management Skills, Using Software Tools. ICTERI 2019: 15 th International conference on ict in education, research, and industrial applications. [Electronic resource]. Kherson, Ukraine. CEUR Workshop Procee ings, 1, 370-384. 2387/20190370.pdf http://ceur-ws.org/Vol-

Shtepura, A. (2018). Forms and methods of distance education in the higher education system of Poland. Bulletin of Chernihivskokho nationalo-pedanonicho University named after T.Kh. Shevchenko, 151(1), 152-155. http://nbuv.gov.ua/UJRN/VchdpuP_2018_1 $51 \% 281 \% 29 \_35$

Stepaniuk, K. (2021). Professional training of future primary school teachers in the context of the priorities of the concept of the New Ukrainian School. Young and market [Molod i rynok], 2, 121-125. http://mir.dspu.edu.ua/article/view/230537/2 29506

Unesco (2020). UNESCO convenes an emergency meeting of the Principals of Multilateral Education Partners to join hands in education response to COVID-19 pandemic.

https://en.unesco.org/news/unescoconvenes-emergency-meeting-principalsmultilateral-education-partners-join-hands

World Economic Forum (2020). Schools of the Future. [Electronic resource]. https://www.greenschool.org/insights/worldeconomic-forum-schools-of-the-future-2020 